\author{
Abstracta Iranica \\ Abstracta Iranica Revue bibliographique pour le domaine irano-aryen \\ Volume 37-38-39 | 2018 \\ Comptes rendus des publications de 2014-2016
}

\title{
Julia Gonnella, Jens Kröger (eds.). Wie die islamische Kunst nach Berlin kam: der Sammler und Museumsdirektor Friedrich Sarre (1865-1945)
}

Frantz Chaigne

\section{OpenEdition}

Journals

Édition électronique

URL : http://journals.openedition.org/abstractairanica/42764

DOI : $10.4000 /$ abstractairanica.42764

ISBN : 1961-960X

ISSN : 1961-960X

Éditeur :

CNRS (UMR 7528 Mondes iraniens et indiens), Éditions de l'IFRI

\section{Référence électronique}

Frantz Chaigne, « Julia Gonnella, Jens Kröger (eds.). Wie die islamische Kunst nach Berlin kam: der Sammler und Museumsdirektor Friedrich Sarre (1865-1945) », Abstracta Iranica [En ligne], Volume 37-38-39 | 2018, document 22, mis en ligne le 10 mars 2018, consulté le 02 octobre 2020. URL : http:// journals.openedition.org/abstractairanica/42764; DOI : https://doi.org/10.4000/abstractairanica. 42764

Ce document a été généré automatiquement le 2 octobre 2020.

Tous droits réservés 
Julia Gonnella, Jens Kröger (eds.). Wie die islamische Kunst nach Berlin kam: der Sammler und Museumsdirektor Friedrich Sarre (1865-1945)

Frantz Chaigne 


\section{RÉFÉRENCE}

Julia Gonnella, Jens Kröger (eds.). Wie die islamische Kunst nach Berlin kam: der Sammler und Museumsdirektor Friedrich Sarre (1865-1945), Berlin, Reimer, 2015, 160 p., 50 ill. couleurs \& 30 ill. n\&b. ISBN 978-3-496-01544-4

Ce volume richement illustré a été édité à l'occasion de l'exposition qui s'est tenue au Museum für Islamische Kunst de Berlin, pour la commémoration du $150^{\mathrm{e}}$ anniversaire de la naissance de Friedrich Sarre (1865-1945). Composé d'un prologue et de huit essais, il permet d'une part d'aborder les multiples facettes de la personnalité de ce personnage (archéologue, érudit, collectionneur, diplomate, directeur de musée, etc.), mais aussi la réception des arts de l'Islam en Allemagne ainsi que le goût pour l'orientalisme qui l'accompagne. Concernant plus spécifiquement les arts de l'Iran, on retiendra surtout les essais de Julia Gonnella (« Friedrich Sarre als Sammler islamischer Buchkunst»,i.e "Friedrich Sarre en tant que collectionneur des arts du livre islamiques», p. 103-120), de Claus-Peter Haase («Kalligraphien der Sammlung Friedrich Sarre », i.e "Calligraphies de la collection de Friedrich Sarre », p. 121-36) et de Jens Kröger («Friedrich Sarre und die orientalischeTeppischkunst», i.e «Friedrich Sarre et l'art du tapis oriental », p. 137-45).

\section{AUTEURS}

\section{FRANTZ CHAIGNE}

Chercheur associé, CNRS, Orient \& Méditerranée-«Islam médiéval» 